\title{
TEACHING COMPETENCY OF PROSPECTIVE TEACHERS IN CHENNAI DISTRICT
}

\author{
Mr.S.Dharmaraju1 ，Dr.K.Saikumari² \\ ${ }^{1}$ Guest Lecturer of Education, Institute of Advanced Study in Education, Saidapet, Chennai - 600015. \\ ${ }^{2}$ Assistant Professor of Biological Science, Institute of Advanced Study in Education, Saidapet, Chennai - 600015.
}

\begin{abstract}
The present study was undertaken to measure the Teaching Competency of Prospective Teachers in Chennai District, Tamilnadu with regard to their gender and locality. For this purpose, 600 Prospective Teachers (200 male and 400 female) from Chennai District were selected from 18 colleges. A Self-constructed and standardized Teaching Competency (TCS) scale was used for data collection and an independent' $t^{\prime}$ test was used for data analysis. Results revealed that there was a significant difference in the Teaching Competency of prospective teachers in relation to their gender and locality.
\end{abstract}

\section{INTRODUCTION}

The main aim of this research is to find the competency of trainee teachers. Teachers always play a major role in student's life. Many students keep their school teachers as their role model, next to their parents. So, trainee teachers being the creator of future world i.e., students first of all, they should posses certain qualities. More than subject knowledge, the teacher should posses certain qualities like following moral values, pure-minded, being unbiased, wide thinker, etc.

In present situation, we come to know from newspapers that very few teachers are there by doing some irrelevant things that become a black mark in teacher's society. In olden days, traditionally guru and their disciplines will be there. Guru will not take everyone as their disciplines. First of all, guru will check the quality of students come under him. Later, continuously seeing his student's character and quality, after continuous examining, he will announce one student, with all good qualities of teacher, as the next guru. But, today in our modern society, if a student scores high marks in their school or in under graduate degree they pursue B.ED or D.TED and become a teacher in a school. The question is, getting degree to become teacher is enough or the teacher should posses some qualities or not. Definitely teachers should posses the above said qualities, because they are at the position in creation of future world. For that the researcher in this study took teaching competencies of prospective teachers.

The main quality of a teacher is maintaining a positive relationship with students. A teacher will not going to interact with machines, he is going to interact with living human beings. So, trainee teachers should maintain good relationship with parents, teachers and the society. If he didn't posses good social relationship, then he will be considered as socially ill-adjusted. A socially ill-adjusted teacher will not make a better society i.e., students.

A teacher trainee teaching competency includes his personal efficiency in teaching viz., being keen in subject matter, positive gestures towards students while teaching, scheduling the units to be taken, usage of teaching aids wherever needed while teaching, making a pleasant environment for students in teaching learning process.

The ultimate need of this research is to find teaching competencies of prospective teacher.

\section{REVIEW OF LITERATURE}

Koksal Necla (2014) conducted a study on "Competencies in teacher education, Pre-service teachers' perception about competencies and their attitudes." The results revealed that a positive and meaningful relationship between general teaching competency perceptions and attitudes towards the profession.

Gokalp, Murat (2015), Studied "Investigating classroom teaching competencies pre-service Elementary Mathematics teachers." The findings indicated a significant and positive relationship between the sub-dimensions of pre-service teachers' teaching competencies. But a significant difference was found between competency scores in terms of different grade levels. 


\section{International Advanced Research Journal in Science, Engineering and Technology \\ Impact Factor 7.105 ㄷ Vol. 9, Issue 1, January 2022 \\ DOI: 10.17148/IARJSET.2022.9147 \\ OBJECTIVE}

2.01. To find out the significant difference in teaching competency of male and female prospective teachers with respect to Gender.

2.02. To study the teaching competency of rural and urban prospective teachers with respect to locality.

\section{HYPOTHESES}

The hypotheses of the study were:

HO 1. There is no significant difference between the teaching competency of male and female prospective teachers with respect to Gender.

H0 2. There is no significant difference between the teaching competency of rural and urban prospective teachers with respect to locality.

\section{METHODOLOGY}

The total sample of the study comprised 600 Prospective teachers (200 Male and 400 Female) of the age group of $<25$ and above 25 years studying in Chennai District, Tamilnadu. The simple random sampling technique was used for the selection of 18 colleges ( 2 Government, 4 Government Aided, and 14 Self-financing colleges) and a simple random sampling technique was used to select the students' sample. The tool used for data collection was the Teaching Competency Scale (TCS) constructed and standardized by the investigator with the help of the research supervisor.

\section{ANALYSIS AND INTERPRETATION}

The mean, S.D, and t-value were calculated from the statistical analysis of data. The Mean score of female and male prospective teachers on teaching competency scores was calculated as 164.50 and 161.11 with S.D. 13.228 and 15.335 respectively. As shown in Table 1 . The obtained t-value was 2.805 which are greater than the table value at 0.05 level of significance. Thus, the null hypothesis is (H0-1) that there is no significant difference between the teaching competency of male and female prospective teachers with respect to Gender, is rejected. In other words, there was a significant difference in the teaching competency of male and female prospective teachers.

Table.1: Significance of Difference between the Male and Female prospective teachers teaching Competency.

\begin{tabular}{|l|l|l|l|l|l|l|l|}
\hline \multicolumn{2}{|l|}{} & $\mathrm{N}$ & $\mathrm{M}$ & $\mathrm{S} . \mathrm{D}$ & $\begin{array}{l}\text { Calculated } \\
\text { Value }\end{array}$ & $\begin{array}{l}\text { Tabulated } \\
\text { Value }\end{array}$ & $\begin{array}{l}\text { Significance } \\
\text { / result }\end{array}$ \\
\hline $\begin{array}{l}\text { Teaching } \\
\text { Competency }\end{array}$ & Female & 400 & 164.50 & 15.335 & 2.805 & 1.96 & $\mathrm{~S}$ \\
\cline { 2 - 7 } & Male & 200 & 161.11 & 13.228 & & $\mathrm{n}$ \\
\hline
\end{tabular}

Table.2: Significance of Difference between the Rural and Urban prospective teachers teaching Competency.

\begin{tabular}{|l|l|l|l|l|l|l|l|}
\hline \multicolumn{2}{|l|}{ Variable } & $\mathrm{N}$ & $\mathrm{M}$ & $\mathrm{S} . \mathrm{D}$ & $\begin{array}{l}\text { Calculated } \\
\text { Value }\end{array}$ & $\begin{array}{l}\text { Tabulated } \\
\text { Value }\end{array}$ & $\begin{array}{l}\text { Significance } \\
\text { / result }\end{array}$ \\
\hline $\begin{array}{l}\text { Teaching } \\
\text { Competency }\end{array}$ & Rural & 376 & 162.49 & 14.135 & \multirow{2}{*}{1.999} & 1.96 & $\mathrm{~S}$ \\
\cline { 2 - 7 } & Urban & 224 & 164.85 & 13.796 & & \\
\hline
\end{tabular}

Table 2 indicates that the Mean scores of urban and rural students were 164.85 and 162.49 with S.D. 13.796 and 14.135 respectively. The calculated t-value is greater than the tabulated value at 0.05 level of significance. Hence, the null hypothesis (N0-2) that there is no significant difference between the teaching competency of rural and urban prospective teachers with respect to the locality, is rejected. It implies that the teaching competency in the urban and rural areas of prospective teachers is differing significantly in their teaching competency scores, with respect to their locality.

\section{CONCLUSION}

The findings and discussion in this study reveal that the place of habitation is a decisive factor in the process of teaching competency of prospective teachers. Obviously, there are challenging aspects of adjustment for the prospective teachers and they have their own way of addressing such challenges and occupy their position in the mainstream society with the potential of flourishing as resourceful social beings. But the way of teaching practice is different for male and female prospective teachers. The female prospective teachers have a better way of teaching skills than their male counterparts. It is noticed that the social interaction of female prospective teachers is closely monitored and guided by her elders and 


\section{International Advanced Research Journal in Science, Engineering and Technology \\ Impact Factor $7.105 \div$ Vol. 9, Issue 1, January 2022 \\ DOI: 10.17148/IARJSET.2022.9147}

in this way she acquires the skill to counter social intricacies fast. Thus, the study on the teaching competency of prospective teachers revealed that students were found to have significant differences in their teaching competency scores with respect to their gender and locality.

\section{REFERENCE}

Best, W. James \& Khan, V. (1989). Research in Education (6 $6^{\text {th }}$ ed). New Delhi: Prentice Hall of India Pvt. Ltd.

Chandha, S.S (1979), A study of some psychological and social factors as related to vocational aspirations of rural and urban high school children. Third Survey of Research in Education (1978-1983). New Delhi: NCERT.

Gokalp, Murat (2015): Investigating classroom teaching competencies of pre-service Elementary Mathematics teachers. Eurasia Journal of Mathematics, science and technology education, 2016, 12(3) PP-503-512.

Koksal Necla (2014): Competencies in teacher education, Pre-service teachers' perception about competencies and their attitudes. African Journal of Philoshophy, 1(1) PP-1-7.

Santrock John. W. Educational Psychology: Second Edition. Mcgraw Hill Publication. 